\title{
JUAN SIN TIERRA (1848), UN DRAMA ROMÁNTICO «SHAKESPEARIANO" ORIGINAL DE JOSÉ MARÍA díAZ
}

\author{
JosÉ LuIS GonZÁlez SubíAS
}

\section{ESTRENO, REPRESENTACIONES Y RECEPCIÓN CRÍTICA DE LA OBRA}

En 1848, José María Díaz era un conocido poeta dramático residente en la capital española, cuyas obras, abundantes ya entonces, sin embargo no habían conseguido calar definitivamente en los gustos del público madrileño. La mala racha de fracasos que el dramaturgo había ido acumulando en los últimos años vino a ser interrumpida por un nuevo título que, sin duda alguna, constituye no sólo el primer gran éxito teatral del literato, sino uno de los más importantes de toda su producción. Nos referimos al «drama original en cuatro actos y en verso» titulado Juan sin Tierra.

Ya a comienzos de julio de ese año, el drama de José María Díaz había sido leído por el comité del Teatro del Príncipe ${ }^{1}$ y en octubre estaba dispuesta su representación en dicho teatro ${ }^{2}$. El estreno de Juan sin Tierra se verificó el $1 .^{\circ}$ de diciembre de 1848 , a beneficio de Bárbara Lamadrid. La obra, que había sido adquirida por el Ayuntamiento de Madrid en 4.000 rs. para la temporada teatral del Teatro del Príncipe de 1848 a $1849^{3}$, permaneció en cartel hasta el día $13^{4}$. Más de diez funciones seguidas era un triunfo excepcional durante el período romántico, lo cual nos indica ya el éxito que debió obtener esta pieza, que cinco días después de su estreno

1 Según La Luneta, 2-VII-1848.

2 La Luneta, 15-X-1848.

3 Archivo de la Villa de Madrid, 4-68-102, 4-70-15.

4 Aunque la Cartelera teatral madrileña, (II: 1840-1849), Madrid, CSIC, 1963, indica que sólo se representó hasta el día 11, El Clamor Público sigue anunciando para el día 13 su representación. Por su parte, David T. GIES (El teatro en la España del siglo XIX, Cambridge University Press, 1996, p. 262) habla de once funciones; y Alfonso PAR (Representaciones shakespearianas en España, Madrid, Victoriano Suárez, 1936, p. 177) señala expresamente que la obra permaneció en cartel los días $1,2,3,4,5,6$, $7,8,9,10$ y 13 de diciembre. 
todavía seguía dando «muy buenas entradas» al Teatro del Príncipe ${ }^{5}$; pero este dato viene avalado, además, por un buen número más de representaciones en otros teatros, tanto dentro como fuera de la capital, así como por dos ediciones de la obra y una crítica absolutamente favorable de la misma.

El 21 de marzo de 1849 el drama fue representado en el Teatro del Circo, y los días 21 y 22 de mayo de nuevo en el Teatro Español ${ }^{6}$. En los carnavales de dicho año, se representó igualmente en el Teatro Principal de Sevilla ${ }^{7}$; a comienzos de mayo en el teatro de Córdoba ${ }^{8}$; en esa misma primavera se representó de nuevo en el Liceo de Barcelona y, «al mismo tiempo», en el Teatro Principal ${ }^{9}$; en el mes de junio en Murcia ${ }^{10}$ y Grana$\mathrm{da}^{11}$, y en octubre en Ciudad Real ${ }^{12}$.

El elevado número de funciones de que gozó Juan sin Tierra queda definitivamente manifiesto con los datos aportados por Alfonso Par en su inapreciable obra Representaciones shakespearianas en España ${ }^{13}$, con ayuda de los cuales hemos confeccionado el siguiente cuadro en el que figuran las representaciones de Juan sin Tierra efectuadas en Madrid y Barcelona a lo largo de buena parte de la segunda mitad del siglo XIX:

\section{MADRID}

1848 1849

Teatro del Circo (21 de marzo)

Teatro Español (21 y 22 de mayo)

1851 Teatro del Drama (17 y 18 de febrero)

1852

1854

1855

1857

\section{BARCELONA}

\author{
Teatro Liceo (1 y 8 de febrero) \\ Teatro Principal (8, 9 y 18 de febrero) \\ Teatro Nuevo de Gracia (23 de agosto) \\ Teatro de la Barceloneta (3 de octubre) \\ Teatro Odeón (19 y 25 de marzo; 4 de abril) \\ Teatro Variedades (11 de febrero) \\ Teatro Calderón (7 de octubre) \\ Teatro del Circo Barcelonés (16, 17, 18 de \\ enero) \\ Teatro Odeón (9 de agosto)
}

\footnotetext{
5 El Clamor Público, 6-XII-1848.

6 Según la Cartelera teatral madrileña (op.cit.). La representación durante el mes de mayo en el Teatro Español puede verificarse en La Ortiga (3 y 31 de mayo de 1849).

7 La Luneta, 4-III-1849.

$8 \quad$ La Luneta, 13-V-1849.

9 Así lo afirma D. T. GIES (op.cit., p. 263).

10 La Luneta, 17-VI-1849.

$11 \quad$ La Ortiga, 25-VI-1849.

12 La Ortiga, 1-X-1849, 21-X-1849.

13 Alfonso PAR, op.cit.
} 
$\mathbf{1 8 6 1}$ Teatro Novedades $(15,16,17$ de abril)
$\mathbf{1 8 6 2}$
$\mathbf{1 8 6 3}$
$\mathbf{1 8 6 5}$
1866

1868
1870
1871

1872
1873
1878
1880
1882

Teatro Odeón (21, 23, 25 de marzo; 31 de agosto)

Teatro de Oriente ( 2 de febrero)

Teatro Tirso (17 de diciembre)

Teatro Tirso $(13,14$ de enero)

Teatro Triunfo (23 de diciembre)

Teatro Variedades (12 de abril)

Teatro Odeón (30 de abril)

Teatro Talía (27 de agosto, 3 de septiembre; 22 y 29 de octubre)

Teatro Talía (1 y 7 de enero)

Teatro Odeón (1 de junio)

Teatro Buen Retiro (3 de febrero)

Teatro del Prado Catalán (17 de octubre)

Teatro Novedades ( 8 y 10 de abril)

Teatro Tívoli (22 de octubre)

A la vista de este esquema, dos conclusiones son obvias; por un lado, el número de representaciones de Juan sin Tierra nos habla de una pieza teatral de enorme éxito y, por otro, éste se manifiesta de manera rotunda en Barcelona frente a Madrid.

El mismo día de su estreno, la obra terminó de imprimirse en los talleres de la imprenta de la Sociedad de Operarios del mismo Arte. Existe una segunda edición, de 1863, sin variaciones apreciables en el texto - sólo en la tipografía y en pequeñas cuestiones ortográficas-, impresa igualmente en Madrid, en la imprenta de José Rodríguez. Díaz dedicó esta última a los actores Carlos Latorre y Julián Romea.

Un tercer factor que distingue esta pieza de las anteriores producciones del autor, decíamos, es la favorable acogida que tuvo por parte de la crítica de la época. Desde El Clamor Público, Juan sin Tierra se califica sin reservas como «el mejor drama de cuantos ha visto el público esta temporada» ${ }^{14}$. Afirmación que es sostenida en términos semejantes desde el periódico La Esperanza: «Uno de los mejores dramas que se han representado en la temporada actual...» ${ }^{15}$. Y no es más tímido el requiebro que, desde La Luneta, se dedica al drama: «una de las producciones más notables que se han representado en la escena durante el año cómico que va corriendo» ${ }^{16}$. Según esta revista teatral, «el público aplaudió mucho y como lo merece el trabajo del Sr. Díaz, llamándole a escena»; y Manuel Cañete, desde El Heraldo, confirma que el autor fue «llamado a escena una vez y otra» ${ }^{17}$. Incluso este célebre crítico tan poco afecto al señor Díaz hubo de

\footnotetext{
14 El Clamor Público, 5-XII-1848.

15 La Esperanza, 4-I-1849.

16 La Luneta, 10-XII2-1848.

17 El Heraldo, 11-XII-1848.
} 
admitir, aun con muchas reticencias, la importancia de esta obra en el panorama escénico nacional, por su novedad respecto al tipo de teatro que venía representándose desde hacía tiempo en Madrid. La obras a que alude Cañete son «frívolas comedias», «literatura de agua chirle, que ni conmueve ni causa interés». No es que se desviva el crítico en elogios por Juan sin Tierra ni por su autor, pero sí destaca el arrojo de éste al llevar a las tablas un teatro distinto al que parecía entonces satisfacer las apetencias del público. En su opinión, el mérito de Díaz

se reduce, simplemente, al buen instinto literario con que ha sabido elegir el original de su obra, a varios rasgos felices, y a la fe con que la ha puesto en escena sin arredrarse ante el viciado gusto del público ${ }^{18}$.

Gran parte del éxito de la obra, en su estreno, debería atribuirse a su puesta en escena y, como se'afirma desde La Luneta, a la «buena ejecución de los actores» ${ }^{19}$. Efectivamente, el elenco de intérpretes que dieron vida a los personajes principales del drama estaba encabezado por cuatro de los actores más celebres y representativos del teatro romántico español: Julián Romea, en el papel del Rey Juan; Carlos Latorre como Hubert, gobernador de la Torre de Londres; Teodora Lamadrid en el papel del joven Arturo, duque de Bretaña; y Bárbara Lamadrid como madre de Arturo y duquesa de Bretaña. Pero no sólo estas grandes figuras del arte dramático contribuyeron a embellecer con su esfuerzo la obra del señor Díaz; como algo excepcional, desde la citada revista teatral se alude a «los demás actores», que «a la manera que el soldado más cobarde cobra bríos cuando le alienta la confianza de un hábil general, no deslucieron el cuadro y nos parecieron menos malos que otras veces».

Sin embargo, no todo fueron elogios para el nuevo drama de José María Díaz. Según el mismo autor reconoce en una nota introductoria al mismo, su obra se inspira en el King Yohn de Shakespeare y en la versión de Ducis titulada Jean sans Terre ${ }^{20}$. En la comparación que el periódico La Ilustración realiza entre éstos y el Juan sin Tierra de Díaz, el último sale bastante mal parado, juzgado como «muy inferior» tanto al drama de Shakespeare como al arreglo del francés Ducis. Aunque reconoce merecido «el asombroso éxito» obtenido por esta pieza, el crítico del citado periódico opina que están «olvidados los principales pensamientos, los ejes [...] so-

18 El Heraldo, 5-XII-1848.

19 La Luneta, 10-XII-1848.

20 Jean François Ducis: Poeta francés (1733-1816). Trató de dar a conocer a Shakespeare en Francia, acomodándolo al gusto del público de la época. Adaptó, entre otros dramas - además de El rey Juan-, a la escena francesa Hamlet, Romeo y Julieta, El Rey Lear, Macbeth y Otelo. Aunque sus obras quedan lejos de la grandeza del teatro shakespeariano, popularizó el teatro del poeta inglés en Francia. 
bre los cuales gira la obra inglesa», y que el interés de la acción está mal distribuido. Culmina finalmente su alegato con esta irónica y ambigua afirmación sobre la calidad del dramaturgo:

Si en versos españoles caben pensamientos Shakspearianos [sic], sólo este autor puede hacerlos, pues su dureza y poca armonía los hace hermanarse perfectamente con la dureza y poca armonía de los pensamientos ${ }^{21}$.

\section{LAS FUENTES DE JUAN SIN TIERRA. ¿DRAMA ORIGINAL O PLAGIO?}

Tendremos ocasión más adelante de volver a escuchar la opinión de la crítica romántica sobre algunos aspectos puntuales del drama. Oigamos ahora al autor en esas palabras preliminares de la obra, donde asegura:

He escrito este drama teniendo muy presente la magnífica tragedia de Shakspeare [sic] y la no menos interesante de Ducis. He seguido en cuanto me ha parecido conveniente la disposición clásica que dio este último al asunto. Cada pueblo tiene sus gustos, como cada hombre sus caprichos. No sé si he acertado con la afición literaria del público español. He creído justas, indispensables, las innovaciones hechas por mí, y a las que darán el valor y la importancia que se merecen los que conociendo el verdadero estado de nuestras costumbres y de nuestra literatura, se tomen el trabajo de leer este drama.

Según Alfonso Par, la afirmación que Díaz vierte en su nota no responde exactamente a la verdad. El dramaturgo romántico copió prácticamente los tres primeros actos del drama de Ducis, adaptación galoclásica del King Yohn shakespeariano. Tan sólo el acto cuarto es original del autor, y en éste los elementos que incluye «son de pura filiación romántica y casi podríamos decir zorrillesca» ${ }^{22}$. La única huella auténtica de Shakespeare en el drama de Díaz se halla en la figura de Constanza enloquecida y en las últimas palabras pronunciadas por Juan sin Tierra. Es, pues, Ducis en quien se «inspira» nuestro dramaturgo para escribir uno de sus mayores éxitos teatrales. Pero, además, casi con toda seguridad extrajo Díaz algunos materiales de Les enfants d'Edouard (1833), de Delavigne, o de la traducción realizada por Bretón de los Herreros (1835); obra inspirada en el Ricardo III, «emblema de nuestra interpretación romántica de Shakespeare».

Según Par, de la mezcolanza entre el Ricardo III y el distorsionado Rey Juan de Ducis, a través de la refundición del primero en Los hijos de Eduardo, de Delavigne, surgieron

$21 \quad$ La Ilustración, 28-IV-1849.

22 Alfonso PAR, op.cit., p. 179. 
una serie de Ricardos, Eduardos y Juanes en los que varían las proporciones originarias y las añadidas en cada compuesto, sin que éste deje nunca de responder a un rey tirano que mata a sus sobrinos, episodio del Ricardo III que el romanticismo convirtió en tema principal y ante el que se desahogaron los corazones sensibles y los ojos lacrimosos de nuestros abuelos ${ }^{23}$.

Respecto al Jean sans Terre (1791) de Ducis, la fuente directa de Juan sin Tierra, en su obra el dramaturgo francés suprimió del King Yohn cuanto se relacionaba con la lucha entre Francia e Inglaterra, reduciendo el argumento a la prisión y asesinato de Arturo por su tío. Ducis toma de Shakespeare sólo una escena, cuando Hubert, después de preparar los hierros para cegar a Arturo, movido a compasión, decide desobedecer al tirano y facilitar la fuga del príncipe. Ésta es, precisamente, la única escena del drama de Díaz que guarda alguna clara semejanza con el original inglés. En opinión de Par, si el dramaturgo español «partió de Ducis, no fue para volver a Shakespeare, sino para construir una tragedia romántica suya»; y al «revestir de perfecto ropaje romántico lo que el escritor francés compuso según los moldes y cortapisas de su escuela», mejoró extraordinariamente la trama de la obra ${ }^{24}$.

Podría afirmarse que, al margen del importante y emotivo episodio de la ceguera y muerte de Arturo, Díaz pretende conducir desde un principio la trama hacia la conjura contra el rey que tendrá lugar en la abadía de Bourgvert, intercalando escenas en los tres primeros actos que anticipan y preparan el último y definitivo. Es sintomático el hecho de que Díaz, frente a Ducis, no haga morir a Constanza junto con Arturo a manos del tirano, puesto que la necesita como elemento inprescindible del acto cuarto.

Cuanto acabamos de señalar conduce a formularnos la siguiente pregunta: ¿Es Juan sin Tierra un «drama original», como pretende su autor, o simplemente una adaptación o, más crudamente, un plagio?

La decisión de José María Díaz de tomar una obra ajena para llevar a cabo sus propósitos artísticos es el mayor escollo que debió sortear el autor en esta ocasión. Es cierto que el drama de Díaz sigue demasiado fielmente al de Ducis, pero también lo es que inspirarse en textos anteriores para realizar una nueva creación literaria original era una práctica habitual en la época y lo había sido durante siglos. Ciertamente, el asunto tratado por Díaz no era novedoso; no sólo se inspiraba directamente en Ducis, sino que, además, había sido dramatizado antes, nada menos que por el mismo Shakespeare; lo cual no deja de manifestar una gran osadía y fe en su capacidad como literato por parte de José María Díaz. No era novedoso, decimos, ¿pero era original?

No habían pasado muchos años desde que el propio dramaturgo, desde

23 Ibíd., pp. 147-148.

$24 \quad$ Ibid., p. 178. 
la Revista de Teatros, denunciara el poco honorable negocio ligado al montaje en los teatros españoles de piezas fraudulentamente originales: «cuando [...] se anuncian como refundiciones traducciones literales, y como producto del ingenio, comedias de otros climas que en ajenos entendimientos se concibieron» ${ }^{25}$. Todo parece indicar que, en Juan sin Tierra, Díaz se acercó demasiado a aquello que él mismo había criticado años atrás. En el Archivo Histórico Nacional se conservan varios documentos en los que se pone de manifiesto la polémica suscitada entre la empresa del Teatro Español y José María Díaz respecto a la pretensión del dramaturgo de impedir las representaciones de su obra, en mayo de 1849, tras haber sido ésta calificada de «no original» por la comisión de lectura ${ }^{26}$.

Después de haber sido representado en el pasado con éxito y sin ningún tipo de problemas, el 20 de mayo de 1849, estando anunciado el drama ya para su puesta en escena al día siguiente en el Teatro Español, la comisión de lectura, en un escrito firmado por Juan del Peral - viejo amigo y compañero de Díaz-, calificó de «no original» el drama. Ese mismo día, en carta dirigida al comisario regio del teatro, Ventura de la Vega, el dramaturgo se defiende de dicha acusación y afirma no reconocer ninguna autoridad en la Junta para dictar tal fallo, negándose a dar su consentimiento para que la obra se represente como mera traducción. En caso de no ser así, el autor amenaza con acudir a los tribunales. Por toda respuesta, Ventura de la Vega alegó que Díaz había enajenado su obra el año anterior al Ayuntamiento, administrador entonces del Teatro del Príncipe, por 4.000 rs., quedando desde ese momento el drama en propiedad del Archivo de los teatros pertenecientes a la corporación municipal. Al haber subrogado el Ayuntamiento el teatro, con sus archivos y dependencias, al gobierno de S.M. para crear el Teatro Español, defiende el comisario regio ser, por tanto, el drama propiedad de la nueva empresa y tener ésta derecho a representar cualquier obra que le pertenezca. Y así se hizo, en efecto, los días 21 y 22 de mayo. El caso pasó a manos del ministro de gobernación, el Conde de San Luis, quien lo puso en conocimiento de la reina. Por orden del 22 de mayo, las representaciones fueron cautelarmente suspendidas hasta que fuera aclarado todo el asunto.

No está claro cómo acabó este litigio en torno a Juan sin Tierra y su condición de drama original o no. Lo cierto es que el 14 de julio de ese año, don Baltasar Anduaga y Espinosa, abogado perteneciente al Consejo de S.M. y Secretario del Gobierno Político de la provincia de Madrid, entre otros $\operatorname{cargos}^{27}$, manifiesta al Ayuntamiento que deberá ceder a José María

25 Revista de Teatros, 23-V-1841.

26 AHN (Consejos, Leg. 50.932, n. ${ }^{\circ} 11$ ).

27 El Jefe Superior era don José de Zaragoza, amigo del autor en los tiempos en que éste le dedicó manuscritamente su poema «A S.M. la Reina Doña María Cristina», publicado en 1840 . 
Díaz el 5\% de los beneficios que se obtengan por el drama cuando éstos sean superiores a 5.000 rs., a partir de la sexta representación ${ }^{28}$.

\section{ANÁLISIS DEL TEXTO}

\section{UN DRAMA DE CONTENIDO SOCIAL}

Pero dejemos estas cuestiones, que poco o nada restan o añaden al valor intrínseco de Juan sin Tierra, y examinemos con detenimiento la obra. En ésta, José María Díaz lleva al teatro un tema que había dejado entrever en anteriores piezas y que estará muy presente en buena parte de su producción teatral: la oposición contra la tiranía y la injusticia. Si en dramas históricos del pasado, el conflicto dramático giraba normalmente en torno al tema del amor, por regla general trágico e imposible, poco a poco vamos observando en las obras del autor un contenido más combativo, coincidente con el progresivo acercamiento de éste hacia posturas ideológicas marcadamente progresistas. Ya en 1836, en Felipe II, Díaz había tratado tímidamente el tema de la injusticia ligada al poder despótico de un monarca, aunque haciendo recaer el peso de tal acusación especialmente sobre sus consejeros. El talante moderado del autor en esos años le impedía lanzar cualquier tipo de baldón excesivo sobre la monarquía. La expresión más acabada de este sentimiento la encontramos en Una reina no conspira (1844), donde, en efecto, las maquinaciones y contubernios aletean en torno a la corona, que queda libre de toda culpa. Las intrigas ligadas al poder, en este caso eclesiástico, habían quedado igualmente al descubierto en Baltasar Cozza (1839). Pero los ensayos más decisivos para hacer del teatro un instrumento crítico a favor de la libertad y de denuncia contra la opresión y la tiranía los encontramos en algunas de las tragedias escritas por el autor en los años cuarenta, como Julio César (1841) y Lucio Junio Bruto (1844).

Nunca antes en la producción del dramaturgo una figura real había salido tan mal parada como en Juan sin Tierra; quizá por eso el autor decidió alejarse de la historia española y poner sus ojos en una emblemática figura de la historia de Inglaterra, conocida por su inhumanidad, sus excesos e injusticias. El rey Juan encarna la figura del tirano por excelencia. Los calificativos denigratorios hacia éste los encontramos profusamente repartidos a lo largo de toda la obra: «déspota inhumano» (escena 1. ${ }^{\mathrm{a}}$, acto I), «vil usurpador» (escena 2. ${ }^{\mathrm{a}}$, acto I), «injusto poder de Juan sin Tierra» (escena 6. ${ }^{\mathrm{a}}$, acto II), «rey usurpador» (escena 1. ${ }^{\mathrm{a}}$, acto III), «tirano rey» (escena 17. ${ }^{a}$, acto III)... Contra dicha tiranía es de justicia que se rebele

28 AHN (Consejos, Leg. 50.932, n. ${ }^{\circ} 11$ ). 
«el pueblo por su rey esclavizado» (escena $3 .^{\mathrm{a}}$, acto I). Pero no es sólo el pueblo quien reclama sus derechos, sino también la nobleza, que anhela «la ansiada resurrección» de sus «santos fueros» (escena 3. ${ }^{a}$, acto IV). Todas estas manifestaciones muestran una misma reivindicación: la libertad y los derechos del hombre frente a la tiranía de un poder autoritario e injusto.

La acusaciones contra el poder despótico de ciertos reyes, por muy monárquico o moderado que pudiera ser aún nuestro autor por entonces, revelan cierto recelo en general contra la institución monárquica: «Milord, ingratitud en todos tiempos / el patrimonio fue de nuestros Reyes» (escena $1^{\mathrm{a}}$, acto IV). Aunque, no obstante, el clima general que se desprende de la obra no muestra en absoluto irreverencia hacia la sangre real ni la corona; muestra de ello es el cariño con que son tratadas las figuras de Arturo y Constanza, su madre.

Interesante es asimismo la consideración que el pueblo, como masa sin voluntad propia, fácilmente manejable por intereses particulares, peligroso en su volubilidad - algo que hemos observado incontables veces en el teatro de Díaz-, le merece a nuestro autor: «... El pueblo es una hoguera / que enciende el más audaz...» (escena 7. ${ }^{\mathrm{a}}$, acto II).

Pero el espíritu crítico de José María Díaz arremete igualmente en esta obra contra la figura del cortesano, encarnación de todos aquellos personajes que, tanto en la ficción como en la realidad, pululan siempre alrededor del poder, astutos y traicioneros, cambiando de rostro según giren los vientos y siempre aguardando su propio beneficio:

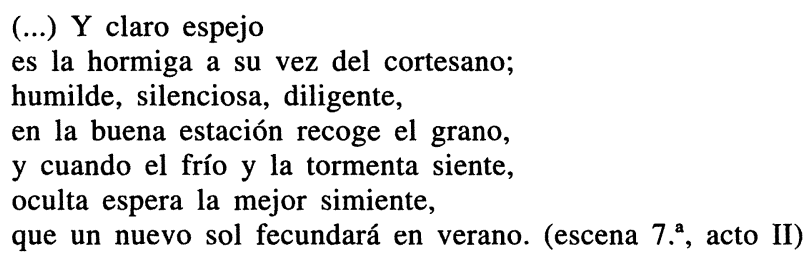

Hay quien ha dicho que «el drama romántico fue eminentemente social, enraizado en los conflictos de su tiempo ante los que hubo de asumir una actitud» ${ }^{29}$. Este teatro, tan conflictivo en cuanto a su contenido, se refugió o proyectó en muchos casos hacia el pasado, desde donde, más distanciadamente - y con menos riesgo-, los poetas podían hacer un teatro comprometido y de denuncia que esquivara con mayor facilidad la censura. Si el fondo liberal, con ribetes antimonárquicos en ocasiones, está presente en muchos dramas históricos románticos españoles ya desde sus comienzos, esta lectura liberal de la historia será la antesala de lo que D. T. Gies ha llamado «primeras obras socialistas», las cuales se valieron fre-

\footnotetext{
29 R. Navas Ruiz, El romanticismo español. Madrid. Cátedra. 1990. pp. 127.
} 
cuentemente del drama histórico como forma de expresión ${ }^{30}$. Entre éstas, el célebre estudioso incluye el Juan sin Tierra de José María Díaz ${ }^{31}$.

\section{Historia y ficción. Argumento de la obra}

En su nuevo drama histórico, Díaz sitúa la acción en el año 1216, en Londres, durante el reinado de Juan sin Tierra. Como hemos podido comprobar en nuestro análisis de otras piezas del autor, éste cuida la ambientación histórica y procura informarse adecuadamente sobre el período en que se ubican los hechos que va a dramatizar; todo lo cual no es óbice para que se permita licencias, anacronismos y la inclusión de numerosos elementos ficticios, si así lo requiere el drama que pretende mostrar en escena. La historia para estos escritores es sólo un marco en el que se desarrollan y desenvuelven las pasiones que atormentan a los personajes que habitan sus dramas; pero se trata de un marco que ha de ser cuidado y tratado con la mayor credibilidad posible.

Anda desacertado Díaz en algunos detalles. Así, por ejemplo, es cierto que el rey Juan muere en 1216, aunque no en el lugar ni en las circunstancias que nuestro poeta imagina para el desenlace de la obra. El joven Arturo, sobrino del rey, se levantó en armas contra éste, reclamando sus derechos a los antiguos dominios de los Plantagenet y otros pertenecientes entonces a la corona de Inglaterra, de los que había sido excluido a raíz del Tratado de Andelys, firmado en el año 1200, entre Juan y el rey de Francia. Arturo fue encarcelado y, según la tradición popular, asesinado por el rey en Ruán, en 1202. Respecto a los acontecimientos de la Carta Magna que aparecen en el acto cuarto, efectivamente éstos se produjeron en 1215, cuando los barones del reino, apoyados por los londinenses, obligaron al rey a jurarla.

Como observaremos en la siguiente sinopsis de la pieza, la realidad se transforma, se adapta y se mezcla libremente con la ficción, sirviendo a los intereses del dramaturgo: El rey Juan, que gobierna despóticamente al pueblo inglés, mantiene en la Torre de Londres a su sobrino Arturo, temeroso del apoyo que el pueblo muestra hacia éste, al que se ha unido gran parte de la nobleza inglesa, ansiosa de recobrar las libertades y fueros que les fueron concedidos en la Carta Magna por Enrique I de Inglaterra, ratificados después por Enrique Plantagenet, y que Juan ha olvidado y pisoteado por completo. La conspiración se extiende a espaldas del monarca y éste, receloso, manda cegar a Arturo. Pero el estallido popular no puede pararse y el rey matará finalmente al joven. Juan, cegado asimismo por su

30 D. T. GIES, op.cit., p. 435.

31 Ibíd., p. 436. 
ambición, acudirá ante los barones del reino a la abadía de Bourgvert, donde será obligado a jurar la Carta y perderá la vida tras tomar un veneno bajo la amenaza de dos de sus propios esbirros.

Por debajo de esta historia subyace todo un cúmulo de pasiones y conflictos entre los distintos personajes que pululan en el drama, que abarcan desde el más profundo y tierno amor, la fidelidad más abnegada, al deseo de venganza, la ambición desmedida o la astucia hipócrita.

\section{ASPECTOS FORMALES Y ESTILÍSTICOS}

\section{Estructura de la pieza}

Un rasgo interesante de esta obra, desde el punto de vista de su construcción formal, es la división de la misma que realiza el autor en cuatro actos, frente a los cinco que venían siendo habituales no sólo en su propia trayectoria teatral sino también en la mayoría de los dramas románticos españoles; quizá en un intento de concentración de la acción o de acercamiento a la estructura clásica en tres actos de la obra de Ducis. Lo cierto es que los tres primeros actos del drama, que según Cañete «están casi enteramente traducidos del de Ducis» ${ }^{32}$, presentan una clara unidad, la cual viene a romperse en el acto cuarto. El cambio de espacio en que sucede la acción es decisivo en esto.

La estructura de la obra fue bastante censurada en su época. Para el crítico de La Esperanza, el final del primer acto era improbable por «dejar suspenso al espectador cortando un diálogo cuando escita [sic] mayor interés, y haciendo caer el telón»; recurso que no juzgaba propio de un drama serio ${ }^{33}$. No podemos compartir esta opinión, ya que dicho efecto, que consiste en dejar una conversación sin acabar, haciendo que los personajes continúen brevemente su diálogo en voz baja hasta que cae el telón, creemos resulta perfectamente adecuado para mantener en vilo al público e incrementar su interés por lo que ocurre en escena. El mismo crítico mencionado reconoce, a pesar de sus reticencias, que se trata de «un rasgo sumamente original». Pero no acaban aquí sus reparos; existe uno que atañe más en concreto a la estructura de la pieza. Según él, «el último acto hubiera debido suprimirse, puesto que puede considerarse como una nueva acción la venganza de Hubert y la muerte de Juan sin Tierra»; por nuestra parte, consideramos que dicho acto está plenamente justificado y es la consecuencia lógica del desarrollo de la historia en los actos anteriores. Si el drama hubiera concluido con la muerte de Arturo, el espectador se hu-

32 El Heraldo, 11-XII-1848.

$33 \quad$ La Esperanza, 4-I-1849. 
biera quedado sin saber en qué deparaba la revuelta contra el rey Juan ni cuál sería la reacción de la atormentada madre del príncipe, o si Hubert llevaría a cabo su promesa de vengar la muerte de éste. Son demasiados interrogantes, que no podrían haber sido resueltos en el mismo acto tercero. Era, por tanto, necesario añadir un nuevo acto. En cuanto a la solución propuesta por el crítico de La Esperanza de situar la venganza de Hubert y la muerte del rey Juan inmediatamente después de la muerte de Arturo, ya que de este modo «no hubiera producido tan mal efecto por la sangre fría con que se ejecuta, transcurrido largo tiempo desde aquella catástrofe», nos parece poco acertada. En primer lugar, era necesario que el rey firmara la Carta Magna antes de que Hubert pudiera cumplir su venganza; es el acuerdo al que había llegado con el conde de Salisbury. Además, la existencia de ese cuarto acto está plenamente justificada, al haber sido anticipado ya desde el acto primero; todo estaba preparado para que el rey acudiera de madrugada a la ábadía de Bourgvert, y Hubert mismo es quien ha tendido la trampa al rey. En cuanto a ese «largo tiempo» que tarda en producirse la venganza desde que Arturo es asesinado, según protesta nuestro crítico, no es tal; no creemos que desde la muerte de Arturo, producida ya de noche, hasta el amanecer, en que sucede el desenlace del drama, haya transcurrido demasiado tiempo como para que el deseo de venganza de Hubert se haya sofocado o enfriado.

Para el crítico de El Heraldo, Sr. Cañete, el interés del drama expira cuando deja de existir Arturo, por lo que «el acto último aparece pegadizo, cuando no sea verdaderamente inútil»; sólo ha sido incluido para ofrecer al público el castigo de Juan sin Tierra, pudiendo - en opinión semejante a la del redactor de La Esperanza- haber sido incorporado al mismo acto tercero. Por otra parte, los dos primeros actos carecen de importancia y todo el interés de la acción «se desarrolla, completa y termina en el tercer acto» ${ }^{34}$.

En cualquier caso, la subjetividad de estas opiniones se pone de manifiesto cuando desde La Luneta se afirma: «Mucho hay que alabar en el arte conque [sic] el poeta ha sabido enlazar el cuarto acto con los otros tres...» ${ }^{35}$.

\section{Personajes}

El análisis de los personajes que intervienen en la pieza nos ofrece de nuevo - aun dentro de la tipicidad propia del drama romántico- un universo rico y variado. Entre la multitud de figuras que pueblan la obra, las principales son el rey Juan, Hubert, Arturo, Constanza y Nevil; seguidas

$34 \quad$ El Heraldo, 11-XII-1848.

35 La Luneta, 10-XII-1848. 
de otras en importancia, como Lord Salisbury, Kermadec o Lord Pembrock. Como ya hemos observado en otros dramas del autor, nos encontramos con un amplio abanico de personajes, con distintos grados de profundidad y caracterización psicológica. Contamos también con un buen número de figurantes (barones ingleses, soldados, pueblo), cuyo papel es meramente auxiliar o de ambientación. Los personajes principales están bien dibujados y mantienen una coherencia entre su psicología y sus palabras y actos; no obstante, hay siempre un rasgo clave en todos ellos que define su carácter y la mayor parte de sus acciones. Así, el rey Juan es un ser tiránico y ambicioso (muy lejos del verdadero carácter de Juan sin Tierra, según Cañete); el personaje negativo de la obra desde un punto de vista ético. Arturo representa la inocencia y la ternura («la figura más bella del cuadro», para Cañete); es la víctima inocente que despierta compasión en el espectador o el lector. Constanza es el amor maternal; Hubert (personaje poco grato a los ojos de Cañete), el recto corazón, así como la mano justiciera de que se sirve Dios para castigar la maldad del rey ${ }^{36}$; y Nevil es un comodín, que vende sus servicios al mejor postor, sin principios, en busca sólo de su propio interés.

Entre las opiniones de la crítica sobre los personajes del drama, amén de los escuetos comentarios de Cañete al respecto, sólo hemos encontrado una leve mención a la actitud del rey Juan al final del acto tercero y otra sucinta alusión al carácter de Hubert. Según el crítico de La Esperanza, el asesinato brutal de Arturo «desmiente algún tanto el carácter de Juan sin Tierra ${ }^{37}$. A nosotros, sin embargo, nos parece absolutamente coherente este acto con su personalidad. En cuanto al carácter de Hubert, dicho crítico señala que le ha dado más importancia el autor, «o por mejor decir más parte en su drama que le da Shakespeare en el suyo»; y concluye: «esto algunas veces produce buenos efectos en la escena, pero lógicamente analizado el carácter de este personaje según ha salido de manos del Sr. Díaz, resulta falso y muchas veces fuera del cuadro». ¿Por qué resulta falso nos preguntamos nosotros el carácter de Hubert? ¿Cuál es ese carácter «lógicamente analizado» de que habla el sagaz crítico? Una adecuada cantidad de amor y misericordia hacia el desvalido, mezclada con una justa dosis de deseo de justicia y venganza, no resulta poco creíble a nuestros ojos.

\section{Espacio y tiempo}

Si habíamos hablado anteriormente de un cierto acercamiento estructural al clasicismo en el número de actos utilizados por el autor, siguiendo

\footnotetext{
36 «La omnipotente / mano de Dios, cuando castiga, nunca / el hombre pudo ver, aunque la siente», afirma Hubert en la última escena del drama.

37 La Esperanza, 4-I-1849.
} 
la huella de Ducis, esta concesión clasicista queda de manifiesto igualmente en el tratamiento del espacio y el tiempo. La historia escenificada en Juan sin Tierra se desarrolla básicamente en un mismo espacio. Los tres primeros actos suceden en el interior de la Torre de Londres; lóbrego lugar, idóneo para crear el ambiente adecuado a la tensión dramática que se plasma en escena. Sólo en el acto cuarto se altera la ubicación espacial. En este caso, la acción se sitúa entre las ruinas de una vieja abadía. Tanto en el caso anterior como en éste se trata de espacios plenamente adaptados al gusto romántico. De no ser por ese último acto, que tanto molestaba a la crítica de su tiempo, Díaz habría respetado la clásica unidad de lugar.

Existe una tendencia en José María Díaz a mantener la unidad de tiempo en sus obras dramáticas; algo que se repite de nuevo en Juan sin Tierra, donde la acción dura exactamente veinticuatro horas. Las indicaciones y referencias temporales, además, son continuas en el texto. Así, al iniciarse el acto primero sabemos que está amaneciendo (según reza en acotación); en la escena primera de dicho acto se indica igualmente que todo está preparado para que, al día siguiente, acuda el rey a la abadía; y en la escena séptima del mismo acto se especifica indirectamente que el acto cuarto sucederá de noche, antes de amanecer. En la escena sexta del acto segundo vuelve a insistirse en la cita para el día siguiente en la abadía, «al rayar el alba». Durante la escena décima de dicho acto dan las doce del medio-. día (sólo han pasado unas pocas horas, por tanto, desde el inicio de la obra hasta ese momento) y se anuncia que Arturo debe ser privado de la vista «antes que mueran entre sombras del sol los rayos rojos»; es decir, que ese mismo día, antes de anochecer, deberá cometerse tan espantoso crimen. El acto tercero se inicia por la tarde, no mucho antes de la puesta del sol; lo que sucederá exactamente a partir de la escena número doce. Poco más tarde, en la escena decimoquinta, el rey anuncia que partirán esa misma noche hacia la abadía, a las doce exactamente. Finalmente, si en el acto tercero está anocheciendo, el acto cuarto se desarrolla en plena noche, bajo una intensa luna que baña la escena. Sabemos que aún falta más de una hora para que salga el sol, según se nos indica en la escena primera a través del diálogo entre Lord Pembrock y Lord Derby; lo que sucederá definitivamente en la escena cuarta. Exactamente veinticuatro horas. ¡Magnífica precisión cronométrica!

\section{Aspectos estilísticos}

Por lo que respecta al lenguaje y la versificación, Juan sin Tierra presenta una novedad frente a anteriores dramas del autor. Si en aquéllos, Díaz utilizaba la característica polimetría del drama romántico, dando prioridad al verso octosílabo, ahora escribirá su obra totalmente en endecasílabos, en 
muchos casos rimados libremente, otras veces formando puntuales combinaciones estróficas (destaca la presencia recurrente del terceto), entre los que tan sólo intercala un breve romance en la escena sexta del acto primero.

La belleza de los versos salidos de la pluma de Díaz es algo continuamente destacado por la crítica teatral de la época, como hemos tenido ocasión de comprobar repetidas veces. El crítico de La Esperanza afirma que «el señor Díaz ha derramado ternura y poesía en las dos escenas entre Hubert y Arturo»; incluso, no puede menos que copiar el sueño de éste, «por lo delicado de la expresión y la belleza de las imágenes» ${ }^{38}$. Hagamos nosotros lo mismo.

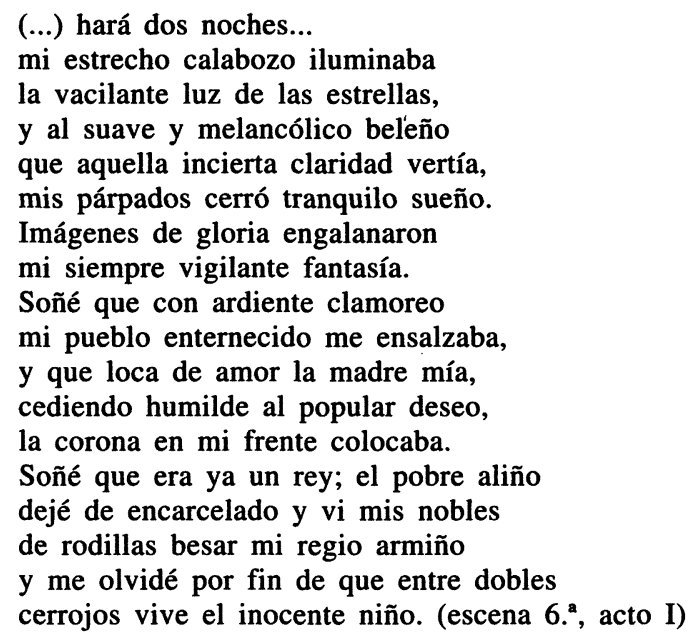

Destaca igualmente el citado redactor como bello y poético el monólogo de Hubert en la escena octava del acto segundo; o la escena octava del acto cuarto, entre el rey y Constanza, que ha perdido la razón después de la muerte de su hijo. Ésta la copiará íntegra, «como muestra de versificación». Curiosamente, el crítico de La Luneta señala que dicha escena fue suprimida en el segundo día de representación de la obra, «porque según hemos oído pareció fría a la parte frívola del público» ${ }^{39}$.

Manuel Cañete, por su parte, no fue tan espléndido en sus elogios. Aunque reconoce que el señor Díaz se ha mostrado en ocasiones «poeta fácil, elegante y enérgico», también deja claro que, en otras, ha rendido tributo «al amaneramiento y al mal gusto que infestan la literatura española contemporánea» ${ }^{40}$. Pondrá como ejemplo del primer aserto los «bellos rasgos y pensamientos felizmente expresados en que abunda el acto terce-

\footnotetext{
38 Ibíd.

39 La Luneta, art. cit.

40 El Heraldo, 11-XII-1848.
} 
ro» (que, por cierto, poco antes había señalado estaba casi enteramente traducido de Ducis), del que destaca especialmente las palabras que Arturo dirige a Hubert cuando mira apagado el fuego, o las primeras palabras de Constanza, cuando acaba de saber que su hijo ha sido cegado. Pero también se recrea en denunciar las «incorrecciones del estilo», y la «flojedad» $\mathrm{y}$ «mal gusto de ciertos pasajes», como, por ejemplo, la plegaria que Hubert dirige a Dios, momentos antes de que aparezca Nevil; ésta le parece de «un gusto deplorable» y procedente de «un manierismo que no tiene disculpa» ${ }^{41}$. Curiosamente, se atreve el crítico a afirmar que, de tener delante el texto de la obra (su crítica la realiza a partir de la impresión que obtuvo en la representación), podría citar ejemplos de las bellezas y defectos del drama; «el cual, a pesar de todo, es menos incorrecto y de mejor gusto que los que generalmente se escriben entre nosotros» ${ }^{42}$.

Un crítico del siglo XX, Alfonso Par, a quien ya hemos acudido en diferentes ocasiones en nuestro estudio sobre esta pieza, coincide en destacar el exuberante lirismo de los versos de Díaz, sus imágenes y cadencia; y señala asimismo que su «modelo es Zorrilla, su maestro y amigo», advirtiendo que el discípulo, no obstante, se queda bastante atrás respecto a aquél. Afirmación gratuita que no responde plenamente a la verdad. Es cierto el parentesco de los versos de Díaz con los de su amigo Zorrilla; familiaridad que, simplemente, procede de un estilo común o semejante, nacido de la pertenencia de ambos a una misma escuela literaria. Por otra parte, es arriesgado hablar del autor del Tenorio como «maestro» de Díaz, cuando en 1837, al abrírsele a aquél las puertas del mundillo literario madrileño a consecuencia de unos afortunados versos, éste ya había estrenado dos importantes dramas históricos y estaba considerado como un prometedor poeta dramático por el mismo Larra ${ }^{43}$.

Con todo, el pretendido elogio que Par parece lanzar sobre Díaz como versificador se ve contrarrestado con la tendencia al ripio que encuentra en éste; algo que, efectivamente, podemos y debemos corroborar, pero que, en

41 Lamentablemente, el buen crítico olvidó dar una referencia más exacta sobre la ubicación de dicho pasaje, del que ni señala la escena en que se encuentra ni copia un mal verso. Quizá, como confiesa él mismo, por no tener el texto delante y escribir su crítica sólo con el vago recuerdo conservado de la representación del drama.

42 La crítica del vaivén es ésta del siglo XIX; se pasa de la cal a la arena con suma facilidad, aparentando diplomacia en unos juicios que, curiosamente, resultan despiadados en bastantes ocasiones y sumamente subjetivos a nuestros ojos.

${ }_{43}$ Par realiza una sorprendente revelación sobre los siguientes versos del Juan sin Tierra: « ¡Oh! ya era tiempo de reír con gana. / El legítimo rey se quedó ciego, / y el rey usurpador muere mañana!» (escena $8 .{ }^{\mathrm{a}}$, acto III). Según este estudioso del teatro shakespeariano, Díaz los copió del Traidor, inconfeso y mártir; afirmación que juzgamos incomprensible, no sólo por no haber hallado dichos versos en el drama de Zorrilla, sino porque éste estrenó su obra tres meses después de que Díaz estrenara la suya, la cual estaba escrita ya antes del mes de julio de 1848 . 
cualquier caso, consideramos común a buena parte de las producciones dramáticas de este período; no sólo de Díaz, sino también de importantes dramaturgos que han sido consagrados por la historia de la literatura española.

Insiste Par en que la falta principal del autor, desde el punto de vista estilístico, es «poner a menudo en boca de los personajes lucubraciones de altos vuelos retóricos, que no tienen nada que ver, e incluso son contradictorias, con sus caracteres». No tenemos nada que objetar al respecto. Efectivamente, la grandilocuencia y el retoricismo impregnan el lenguaje del teatro romántico español; es parte de su estética. Es obvio que este fenómeno puede restar verosimilitud en ocasiones al carácter y al sentimiento de los personajes, pero posee unos efectos poéticos y estéticos que quizá compensen el pretendido defecto anterior. Los parámetros del gusto y la belleza varían de unas épocas a otras, así como la finalidad de los autores al llevar sus obras a escena.

\section{CONCLUSIÓN. JUAN SIN TIERRA, UNA PIEZA EJEMPLAR DEL DRAMA ROMÁNTICO}

Poco más nos queda por decir de esta obra, una de las más sobresalientes del dramaturgo. Multitud de elementos románticos se despliegan en la misma; desde la propia ambientación, pasando por las pasiones que mueven a los personajes y el lenguaje que utilizan, hasta la inclusión del elemento onírico con valor premonitorio recogido en el sueño del joven Arturo. Multitud de detalles asimismo que sirven como muestra de la teatralidad inherente al drama romántico y de la habilidad de Díaz como dramaturgo; así, el bello efecto escénico que el autor utiliza en la escena séptima del último acto, cuando el escenario se oscurece por el paso de una nube, coincidiendo con un intenso y patético monólogo del derrotado rey. Efecto que culmina en las dos últimas escenas del drama, en las que Juan sin Tierra paga sus crímenes con la vida, entre la claridad evanescente de los relámpagos.

Al margen de nuestra mayor o menor sensibilidad para percibir la belleza y la fuerza dramática de estas escenas, hay una realidad que no podemos negar; Juan sin Tierra constituye una pieza clave en el panorama del teatro romántico español, y puede considerarse como uno de los ejemplos más logrados y representativos del mismo, así como del estilo del dramaturgo José María Díaz. Como afirma el propio Par:

El buen éxito de esta tragedia fue fulminante. Díaz había acertado en dar al público, en el momento oportuno, una obra exageradamente romántica, con situaciones emocionantes y grandes tiradas líricas que hacían palpitar los corazones y batir las palmas a los espectadores ${ }^{44}$.

44 Alfonso PAR, op.cit., p. 183. 